\title{
AUMENTO DA RESOLUTIVIDADE DE CONTRATAÇÕES APÓS INCLUSÃO DE TESTE PSICOLÓGICO EM PROCESSO SELETIVO
}

\section{INTRODUÇÃO}

Observamos em nossa instituição como causa mais frequente de não efetivação de colaboradores após período de experiência fatores comportamentais e não deficiência na capacidade técnica. Baseados nisto, nosso hospital localizado no interior paulista capacitou seu psicólogo a realizar teste ${ }^{1}$ e entrevista ${ }^{2}$ diferentes que procuram avaliar se o candidato tem o perfil necessário às competências que estão sendo propostas ao cargo em aberto.

\section{OBJETIVO}

Gerar aumento da resolutividade das contratações de novos colaboradores com a inclusão de teste psicológico e entrevista semi estruturada no processo seletivo da instituição diminuindo os custos com a não efetivação do colaborador.

\section{METODOLOGIA}

0 processo seletivo que inicialmente era composto de 3 fases: $1^{\circ}$ fase = prova teórica e nota mínima de sete. $2^{\circ}$ fase = prova prática e nota mínima sete . $3^{\circ}$ fase $=$ entrevistas com equipe de supervisores, passando a contar com $4^{\circ}$ fase composta por avaliação psicológica que emite parecer técnico recomendando com ou sem restrições a contratação, nessas restrições aparecem pontos fracos a serem desenvolvidos mas que não comprometem o desempenho da função ou parecer pela não contratação mediante análise de padrões de comportamentos e de personalidade e sua não adequação às competências exigidas para o cargo.

\section{RESULTADOS}

Nossa taxa de resolutividade de contratação, ou seja, taxa de contratações de colaboradores ao fim do período de experiência mantinha-se em $88,37 \%$ em agosto de 2017 quando iniciou-se o novo processo de contratações e passou após um ano de início do projeto para 93,4\%, houve melhora de 5,03\% já no primeiro ano.
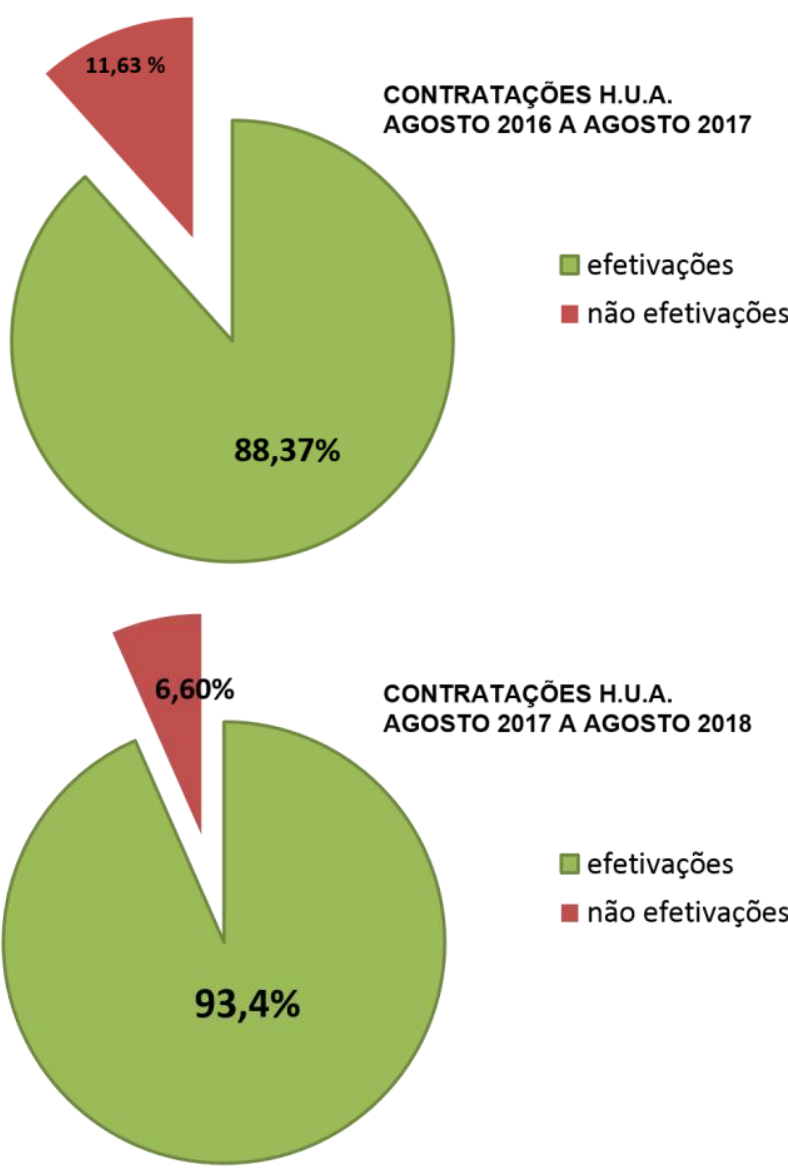

\section{CONCLUSÃO}

Demostramos que buscar profissionais com o perfil psicológico adequado à função traz benefícios financeiros a empresa com a melhora de sua resolutividade de contratações.

\section{REFERÊNCIAS}

1. ALVES, I.C.B. \& E ESTEVES. MEDIDAS PSICOLOGICAS DO CONHECIMENTO E DA INTERVENCÃO PROFISSIONAL. SÃO PAULO: CASA DO PSICOLOGO. O TESTE PALOGRÁFICO NA AVALIAÇÃO DA PERSONALIDADE. SÃO PAULO (2004).

2. PEREIRA, D. F. \& BANDEIRA, D. R. (2009) ASPECTOS PRÁTICOS DA AVALIAÇÃO PSICOLÓGICA NAS ORGANIZAÇÕES.SÃO PAULO.

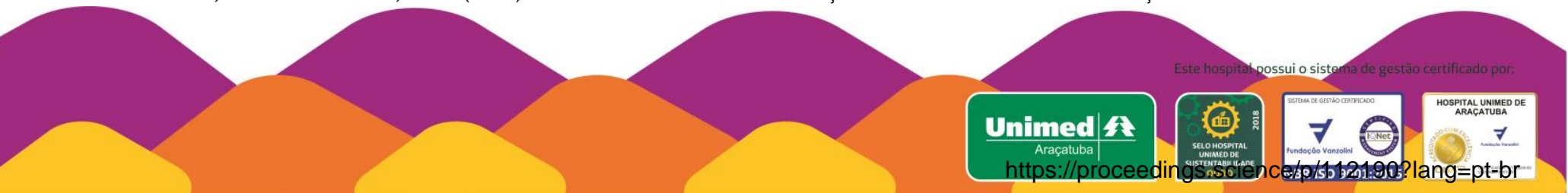

